CHAPTER 10

\title{
Free Movement of Goods in the EAC
}

\author{
Leonard Obura Aloo
}

\subsection{Introduction}

This Chapter addresses the free movement of goods within the East African Community (EAC). A central feature of regional integration and any common market are the "four freedoms" - the free movement of goods, labour, services and capital. ${ }^{1}$ Free movement of goods paves the way for the other freedoms and is usually one of the initial steps in the integration process. Free movement of goods is sometimes referred to as the pioneer economic freedom and it is a key component of the East African integration process. ${ }^{2}$

Free movement of goods means that goods can be moved freely within the defined common territory. ${ }^{3}$ The idea is that the Community will constitute a single economic area similar to the domestic market of any of the Partner States. It is generally agreed that free trade contributes to wealth creation. ${ }^{4}$ Free movement of goods enables a producer in the EAC to have access to a potential market of 143.5 million people. ${ }^{5}$

This Chapter will cover the free movement of goods in the EAC under the Customs Union as well as subsequent developments under the Common Market. Firstly, it will examine the extent to which free movement of goods is envisaged under the Community instruments. ${ }^{6}$ Some historical review will

1 East African Community Treaty (adopted 30 November 1999, went into force 7 July 2000) (EAC Treaty) art 76(1): "There shall be established a Common Market among the Partner States. Within the Common Market, and subject to the Protocol provided for in paragraph 4 of this Article, there shall be free movement of labour, goods, services, capital, and the right of establishment."

2 For the similar role movement of goods played in European integration see EU chapter 9 and 10. P.S.R.F., Mathijsen, A Guide to the European Union Law (8th edn, Sweet \& Maxwell 2004) 173.

4 For the theory of comparative advantage put forward by David Ricardo in 1817 see William J. Baumol \& Alan S. Blinder, Economics: Principles \& Policy (nth edn, South-Western Cengage Learning 2008) 50.

5 EAC Facts \& Figures Report (2014).

6 For the reality on the ground, which sometimes does not accord with what reality intended on paper, see East African common market scorecard 2014: tracking EAC compliance in the 
explain the progression of law under these instruments. Next, there will be a brief examination of the free movement of goods under the Customs Union, including the rules of origin and the rules on elimination of non-tariff barriers. This discussion includes a brief look at developments under the Common Market Protocol. Finally, the chapter examines the question of whether the theory on the free movement of goods accords with the reality experienced by traders.

The Chapter is descriptive and introductory and is intended to enable the reader to navigate through the various EAC instruments dealing with the free movement of goods.

\section{2 Historical Development of the Free Movement of Goods in the East African Community}

Some understanding of the historical development of free movement of goods in the East African region is necessary in order to contextualise the way in which the EAC has developed and continues to develop its rules on the free movement of goods. ${ }^{7}$

The EAC in its current format comprises six states. The founding Partner States which signed the Treaty for the Establishment of the East African Community (the EAC Treaty) in 1999 were Kenya Tanzania and Uganda. They were subsequently joined by Rwanda and Burundi in the year 2007. South Sudan became the sixth Partner State in 2016.

Free movement of goods has already been a central feature of East African cooperation since early in the last century. As early as 1917, Kenya and Uganda established a Customs Union with the amalgamation of their customs authorities. ${ }^{8}$ In 1922, Kenya, Uganda and Tanganyika agreed on a common

movement of capital, services and goods (Vol. 2): Main report (English), < http://documents .worldbank.org/curated/en/2014/01/23862386/east-african-common-market-scorecard2014-tracking-eac-compliance-movement-capital-services-goods-vol-2-main-report> accessed June 282016.

7 For a detailed discussion on the early history of co-operation amongst East African countries see Thomas M. Franck, East African Unity Through Law (Yale University Press 1964); Y.P. Ghai and J.P.W.B. McAuslan. Public Law and Political Change in Kenya: A Study of the Legal Framework of Government from Colonial Times to the Present (Oxford University Press 1970) Chapter 12 and Chapter X above.

8 Ibid. 46o; Henry Kibet Mutai, Compliance With International Trade Obligations: The Common Market For Eastern and Southern Africa (Kluwer Law International 2007) 116-118; See generally Thomas M. Franck, East African Unity Through Law (Yale University Press 1964); See 
external tariff. In 1923, free interchange of domestic products was achieved. Four years later the three territories agreed on free movement of imported goods. ${ }^{9}$ However, these early arrangements were often not legally secured and depended on the goodwill of the parties..$^{10}$ The early Customs Union "was maintained only as a result of inter-territorial negotiations and Kenya-Uganda and Tanganyika retained their separate customs administrations until 1949."11

In 1947, the East African High Commission was established through the East African (High Commission) Order in Council. ${ }^{12}$ The High Commission's mandate did not cover the Common Market sufficiently, with emphasis being placed instead on the common services. ${ }^{13}$ The effectiveness of the Common Market was left to the authority of the Colonial Secretary. Though effective, the benefits of the early Common Market were not evenly distributed amongst the three territories. Just before independence of the three territories in the early 1960 s, the problem was significant enough that a Commission to review the workings of the common services and common market was established. ${ }^{14}$ Between 1961 and 1967 the East African Common Services Organisation was established, briefly providing an anchor for the Common Market. However, due to an uneven distribution of benefits, Uganda and Tanzania imposed restrictions on the access of Kenyan goods into their territories. Efforts to resolve disputes over these restrictions culminated in the establishment of the Treaty of East African Co-operation in $1967 .^{15}$

This Treaty arrangement lasted between 1967 and 1977 and contained elaborate provisions to cover the free movement of goods within the territories in addition to common external tariffs. Despite these provisions, the $1967-$ 1977 Treaty was plagued by many of the same complaints as its predecessor, namely free movement of goods benefiting Kenya at the expense of the other

generally Robert W. Strayer, The Failure of Closer Union in East Africa 1919-1931 (dissertation, University of Wisconsin-Madison 1966).

Y.P Ghai and J.P.W.B. McAuslan. Public Law and Political Change in Kenya: A Study of the Legal Framework of Government from Colonial Times to the Present (Oxford University Press 1970) 460 .

$10 \quad$ Ibid.

11 Ibid.

12 East African (High Commission) Order in Council, S.I. No. 2863 of 1947.

13 Y.P. Ghai and J.P.W.B. McAuslan. Public Law and Political Change in Kenya: A study of the legal framework of government from colonial times to the present. Nairobi. Oxford University Press. 1970. p. 470.

$14 \quad$ Ibid. 472.

15 Ibid. 478. 
territories. ${ }^{16}$ These complaints, coupled with other political factors, led to the eventual collapse of the old EAC. However, the EAC of the 1970s made significant progress towards the free movement of goods within the Community. ${ }^{17}$ Lessons drawn from the collapse of the old Community and the pre-independence arrangements continue to inform the approach towards the free movement of goods in the current Community. ${ }^{18}$ Specifically, safeguards were built into the framework for integration to ensure that the economies that were relatively less developed were not swamped by goods from the relatively better developed economies. The principles of variable geometry and asymmetry are integral to the EAC Treaty. ${ }^{19}$

Under Article 5(2) of the EAC Treaty, the Partner States undertake to establish among themselves and in accordance with the provisions of the treaty, "a Customs Union, a Common Market, subsequently a Monetary Union and ultimately a Political Federation." ${ }^{20}$ In implementing these, the Operational Principles of the Community include the principle of variable geometry, equitable distribution of benefits and principle of asymmetry. ${ }^{21}$

Free movement of goods is an essential feature of a fully-fledged customs union and a given in a functioning common market. ${ }^{22}$ Regional economic integration regimes theoretically proceed from the preferential trade area (PTA) where partners offer each other preferential trade terms relative to the rest of the world, to a free trade area (FTA), where trade amongst the partners is conducted free from tariff and non-tariff barriers. Meanwhile, each partner in the

16 Ngila Mwase, 'Regional Economic Integration and the Unequal Sharing of Benefits: Background to the Disintegration and Collapse of the East African Community' (1979) 4 Africa Development 2/3; Y.P. Ghai and J.P.W.B. McAuslan. Public Law and Political Change in Kenya: A Study of the Legal Framework of Government from Colonial Times to the Present (Oxford University Press 1970) 478.

17 Ngila Mwase, 'Regional Economic Integration and the Unequal Sharing of Benefits: Background to the Disintegration and Collapse of the East African Community' (1979) 4 Africa Development 2/3.

18 Henry Kibet Mutai, 'Regional trade integration strategies under SADC and the EAC: A comparative analysis' (2011) 1 SADC Law Journal 81, go.

19 Ibid. 85.

20 EAC Treaty Article 5(2).

21 EAC Treaty Articles 7(1)(e), 7(1)(f) and 7(1)(h).

22 Report of the Heads of Delegation to the Foreign Ministers at the Messina Conference, 21 April 1956. This report, which emphasized the benefits of the free movement of goods, was presented at the conference and paved the way for future negotiations which culminated in a European customs union and common market (known colloquially as the Spaak Report). 
FTA has an independent trade policy to the rest of the world. Next comes the customs union, where the free trade amongst member states is supplemented by the free movement of goods, and is extended to include free movement of capital, services, labour, and persons and a right of establishment. Finally, the monetary union, has all the aspects of the common market, in addition to cooperation on economic and monetary issues including a common currency. ${ }^{23}$

In practice, regional cooperation does not fit exactly into these theoretical pigeon holes, ${ }^{24}$ and the EAC developments are no exception. The developments in the EAC have been pragmatic, from trade liberalisation to a Customs Union and proceeding to the Common Market. However, not all aspects of the Customs Union are fully implemented as of yet. ${ }^{25}$

With this background in mind, we may now discuss the provisions of the EAC legal regime on the free movement of goods.

\subsection{Free Movement of Goods}

As indicated above, the EAC Treaty was signed on the 30th November 1999. The Protocol on the Establishment of the East African Community Customs Union was concluded five years later in 2004 and implementation began in January 2005. Implementation of the Customs Union was to be progressive for a period of five years. The Partner States have formally eliminated tariffs on goods for intraregional trade. However, measures of equivalent effect, rules of origin, sanitary and phytosanitary measures, additional taxes and charges in addition to technical barriers all remain. ${ }^{26}$ Below we examine the framework for the free movement of goods and the way in which the barriers to trade are dealt with in the EAC.

The legal framework of the Customs Union consists of the EAC Treaty; the Protocols; the laws enacted by the East African Legislative Assembly; the

\footnotetext{
23 EAC, Study on the Establishment of an East African Community Common Market: Final Report (M.A. Consulting Group, August 2007) 10. See on this point also EU Chapter 9.

24 Ibid.

25 Ibid. 11; Bela Balassa, The Theory of Economic Integration (first published in 1961, Routledge 2011) 2 .

26 East African common market scorecard 2014: tracking EAC compliance in the movement of capital, services and goods (Vol. 2): Main report (English), The World Bank/ EAC Secretariat, 4 <http://documents.worldbank.org/curated/en/2014/01/23862386/eastafrican-common-market-scorecard-2014-tracking-eac-compliance-movement-capitalservices-goods-vol-2-main-report> accessed June 282016.
} 
regulations and directives of the Council; relevant principles of internal law; and applicable decisions made by the East African Court of Justice. ${ }^{27}$ The current institutional framework for the implementation of the Customs Union is made up of regional policy organs and national institutions. In respect of customs, the Council is responsible for policy decisions. The Directorate of Customs coordinates the policy development and the customs authorities in each respective Partner State are responsible for the day-to-day customs operations including revenue collection, accountability and enforcement of the East African Community Customs Management Act (EACCMA). ${ }^{28}$ At the national level customs is administered under the revenue authority through national legislation implementing the EACCMA.

\subsubsection{The Protocol on the Establishment of the East African Community Customs Union}

The EAC trade regime is informed by Chapter Eleven of the EAC Treaty which is entitled "Co-operation in Trade Liberalisation and Development". Article 74 of the EAC Treaty provides that in order to achieve the EAC's objectives the Partner States shall adopt an East African Trade Regime and co-operate in trade liberalisation and development in accordance with the regime.

Under Article 75 of the EAC Treaty, the Partner States agreed to establish a Customs Union, details of which were to be contained in a Protocol. Under Article 75(7) of the EAC Treaty, the Partner States agreed to conclude a Protocol on the Establishment of a Customs Union within four years. The EAC Partner States took the unusual route of implementing the free trade area and the customs union simultaneously. ${ }^{29}$ The Protocol on the Establishment of the East African Community Customs Union (the Customs Union Protocol) was signed in March 2004. ${ }^{30}$

The EAC Treaty required the Customs Union Protocol to contain certain details including:

27 EAC, Framework for the Attainment of the East African Community Single Customs Territory (November 2013) 2.1.2(e).

28 East African Community Customs Management Act 2004 (Revised Edition 2009); see also EAC, Framework for the Attainment of the East African Community Single Customs Territory (November 2013) 2.1.2(e).

29 Henry Kibet Mutai, 'Regional trade integration strategies under SADC and the EAC: A comparative analysis' (2011) 1 SADC Law Journal 81, 83. Economic literature suggests the conventional approach would be to move from a free trade area to a customs union and then to a common market. In the EAC the first two stages were implemented together. Protocol on the Establishment of the East African Community Customs Union (2004). 
(a) Application of the principle of asymmetry;

(b) The elimination of internal tariffs and other charges of equivalent effect;

(c) The elimination of non-tariff barriers;

(d) Establishment of a common external tariff;

(e) Rule of Origin;

$(f)$ Dumping;

(g) Subsidies and countervailing duties;

(h) Security and other restrictions to trade;

(i) Competition;

(j) Duty drawback, refund and remission of duties and taxes;

(k) Customs co-operation;

(l) Re-exportation of goods; and

(m) Simplification and harmonisation of trade documentation and procedures. ${ }^{31}$

The Customs Union Protocol dealt with these issues in 44 comprehensive articles. The articles are divided into nine parts. These parts cover interpretation; establishment of the East African Community Customs Union; Customs Administration; Trade Liberalisation; Trade Related Aspects; Export Promotion Schemes; Special Economic Zones; Exemption Regimes; and General Provisions. ${ }^{32}$

The Customs Union Protocol provides that the implementation of the Protocol would be progressive over a five year period ending in 2010. ${ }^{33}$

The most significant aspects of the EAC Customs Union Protocol were: the removal of internal taxes on intra-EAC trade; the removal of non-tariff barriers on intra-EAC trade; the introduction of common external trade policy through the Common External Tariff; the introduction of a list of sensitive products that were to be provided with additional protection; and the legal and institutional mechanisms which have been developed to govern free movement of goods within the EAC. ${ }^{34}$ Having provided an outline of the Customs Union Protocol, we can now examine how it dealt with each of these major areas.

$31 \quad$ EAC Treaty Article 75(1).

32 EAC Customs Union Protocol.

33 EAC Customs Union Protocol Article 11.

34 EAC, Study on the Establishment of an East African Community Common Market: Final Report (M.A. Consulting Group, August 2007). 


\subsubsection{Removal of Internal Tariffs of Intra-EAC Trade under EACCU Protocol}

As indicated above, elimination of internal tariffs on goods under the Customs Union Protocol was envisioned to be progressive and asymmetrical. The Customs Union Protocol defines goods as:

[A]ll wares, articles, merchandise, animals, matter, baggage, stores, materials, currency and includes postal items other than personal correspondence, and where any such goods are sold under the auspices of this Protocol, the proceeds of the sale. ${ }^{35}$

Under Article 11 of the Customs Union Protocol, there was an immediate elimination of duty for goods to and from the Republic of Uganda and the United Republic of Tanzania. ${ }^{36}$ Goods from Tanzania and Uganda destined for Kenya also enjoyed immediate duty free access on coming into force of the Customs Union Protocol. ${ }^{37}$

However, goods from Kenya destined for Uganda and Tanzania were divided into two categories: firstly, those eligible for immediate duty free access to the markets in Uganda and Tanzania were placed in category A; ${ }^{38}$ and secondly, other goods were placed in category B and were eligible for a gradual tariff reduction. ${ }^{39}$ Category B goods from Kenya destined for Uganda had a phased reduction of tariffs of 10, 8, 6, 4 and 2 per cent in each of the first to fifth years respectively and thereafter tariff free access would be applied. ${ }^{40}$ Category $\mathrm{B}$ goods from Kenya destined for Tanzania had a phased reduction of tariffs that was specified in Annex II to the Customs Union Protocol. ${ }^{41}$

Internal tariffs specified in the Customs Union Protocol were not to exceed the Common External Tariff with regard to any of the specified products. ${ }^{42}$

\footnotetext{
35 EAC Customs Union Protocol Protocol Article 1(1).

36 EAC Customs Union Protocol Article 11(2)(a); The language of the is not unequivocal but the intention is clear.

37 EAC Customs Union Protocol Article 11(2)(b).

38 EAC Customs Union Protocol Article 11(3)(a).

39 EAC Customs Union Protocol Article 11(3)(b).

40 EAC Customs Union Protocol Article 11(4); Annex II to the Protocol in respect to Uganda contains 443 categories of goods each with different schedules for reduction of tariffs, see www.eac.int/customs/index . (last accessed 2nd December 2015).

41 EAC Customs Union Protocol Article 11(5); Annex II to the Protocol in respect to Tanzania contains 859 categories of goods each with different schedules for reduction of tariffs, see www.eac.int/customs/index.... . (last accessed 2nd December 2015). EAC Customs Union Protocol Article 11(6).
} 
The current state of implementation of the Customs Union Protocol is that it has now been fully implemented. Since the coming into force of the Customs Union Protocol the Partner States have eliminated internal tariffs and apply a common external tariff. "Goods procured in the region are not subject to import duty when transferred to another Partner State if they meet the rules of origin requirements. The goods are however, subject to domestic taxes (VAT, excise and other levies) levied on international trade upon arrival at the international borders." 43

\subsubsection{Intra-EAC Trade - Common External Tariff}

In a fully flagged customs union states apply a common external tariff on imports. A common external tariff is a commercial policy towards third countries. ${ }^{44}$ In the EAC, due to the progressive approach to integration, there are exemptions to the common external tariff.

Under Article 12 of the Customs Union Protocol the Partner States established a three band common external tariff with a minimum rate of zero per cent, a middle rate of ten per cent and a maximum rate of twenty five per cent in respect of all products imported into the Community. ${ }^{45}$ Exceptional measures may be taken to remedy any adverse effects which any Partner State may experience by implementation of the Common External Tariff. ${ }^{46}$ Rates higher than 25 per cent are applied to some selected items (termed the sensitive list). ${ }^{47}$ These include such items as maize, cement, rice, cotton fabrics, milk and dairy products. ${ }^{48}$ The rates are published in the EAC Common External Tariff Handbook, ${ }^{49}$ and EAC Gazette Notices. ${ }^{50}$

The EAC Customs Management Act provides the legal framework for the implementation of duties and the Common External Tariff. Section 110 of the EAC Customs Management Act indicates that the rate of duty payable shall be the rate specified under the Customs Union Protocol. Goods originating from the Partner States are to be accorded Community tariff treatment in accordance with the Rules of Origin and the Customs Union Protocol. ${ }^{51}$

\footnotetext{
43 EAC Customs Union Protocol Article 25(2)(b).

44 P.S.R.F., Mathijsen, A Guide to the European Union Law (8th edn, Sweet \& Maxwell 2004) 175 .

45 EAC Customs Union Protocol Article 12(1).

46 EAC Customs Union Protocol Article 12(3).

47 EAC Trade Report 2014 Section 5.2.; Sensitive Goods.

48 Ibid.

49 The EAC Common External Tariff (CET) Handbook.

$50 \quad$ EAC Gazette.

$5^{1}$ The East African Community Customs Management Act Section 111.
} 
The classification of goods is in accordance with a Harmonised Customs Commodity Description and Coding System. ${ }^{52}$

The EAC Partner States are also members of other regional trading arrangements which complicates application of the Common External Tariff. Burundi, for example, is a member of the EAC, the Economic Community of Central African States (ECCAS), the Common Market for Eastern and Southern Africa (comesa) and comesa Free Trade Area. Kenya is a member of the EAC, COMESA, and the Intergovernmental Authority on Development (IGAD). Rwanda is a member of the EAC, the ECCAS, COMESA and COMESA Free Trade Area. Tanzania is a member of the EAC and the Southern African Development Community (SADC). Uganda's membership is in the EAC, COMESA, COMESA Free Trade Area and IGAD. ${ }^{53}$ The Customs Union Protocol in Article 37 requires Partner States to honour commitments in respect of all other multilateral and international organisations to which they belong. In particular the Partner States are required to identify the issues arising from membership of other integration blocks in order to establish convergence. Article 37 specifically allows Partner States to enter into other regional arrangements although a procedure for notifying other Partner States is provided. ${ }^{54}$

Under Section 112 of the EAC Customs Management Act, notwithstanding the Common External Tariff, preferential treatment is applied to goods imported under the COMESA and SADC arrangements in the Partner States as prescribed by the Partner States legislation and also for other tariff arrangements approved by the Council. ${ }^{55}$ The preferential treatment for COMESA and SADC was supposed to cease in 2008 , however, the preferential treatment for goods approved by the Council continues. ${ }^{56}$ The multiple and overlapping membership of regional trading arrangements complicates the application of the Common External Tariff and makes the EAC Partner States reluctant to eliminate internal boundaries and also increases the significance of the rules of origin regime..$^{57}$

$52 \quad$ EAC Customs Union Protocol Art. 8 and 12(4).

53 Adam Ihucha, 'Comesa, Sadc imports get tariff relief again' (The East African 5 2013) <http://www.theeastafrican.co.ke/news/Comesa-Sadc-imports-get-tariff-relief-again-/-/ 2558/1658344/-/ugt2mi/-/index.html> accessed July 6, 2016.

54 EAC Customs Union Protocol Article 37.

55 S. 112 The East African Community Customs Management Act.

56 S. $112(2)$ The East African Community Customs Management Act.

57 Ron Sandry, Intra-REC trade and overlapping membership: review of COMESA, EAC, $S A D C$ (Trade Law Centre, August 2015). 


\subsubsection{Removal of Internal Tariffs of Intra-EAC Trade-Rules of Origin}

In order to implement free movement of goods, it is necessary to establish the origin of the goods so as to determine which goods benefit from the rules on free movement and which goods do not. In a fully-fledged customs union, rules of origin are of less significance because states apply a common external tariff. ${ }^{58}$ However, in the EAC due to the progressive approach to integration and the exemptions to the Common External Tariff, an absence of rules of origin would result in trade deflection where goods would enter the region via the country with the lowest external tariff which would deny customs revenue to the other Partner States. ${ }^{59}$

Article 14 of the Customs Union Protocol provides for the rules of origin. The rules specify that goods are accepted as being eligible for the Community tariff treatment if they originate from the Partner States. ${ }^{60}$ Goods are considered to originate from the Partner States if they meet the criteria set out in the EAC Customs Union (Rules of Origin) Rules specified in Annex III to the Customs Union Protocol. ${ }^{61}$

The EAC Customs Union (Rules of Origin) Rules 2015 are the current edition of these rules. ${ }^{62}$ The Rules of Origin provide that the purpose of the rules is to "ensure there is uniformity among Partner States in the application of the Rules of Origin and that to the extent possible the process is transparent, accountable, fair, predictable and consistent with the provisions of the Protocol."63

Rule 4 of the Rules of Origin provides two criteria for goods to be considered as originating in the Partner States.

Firstly, goods are accepted as originating in a Partner State where the goods have been wholly produced in the Partner State from which they are

$5^{8}$ What is the Common Customs Tariff, (European Commission) <http://ec.europa.eu/ taxation_customs/customs/customs_duties/tariff_aspects/index_en.htm $>$ accessed July 6, 2016.

59 Henry Mutai, 'Regional trade integration strategies under SADC and the EAC: A comparative analysis' (2011) 1 SADC Law Journal 81-97 at 86.

6o EAC Customs Union Protocol Article 14(1).

61 EAC Customs Union Protocol Article 14(2) and Article 14(3); East African Community Customs Union (Rules of Origin) Rules, 2015 available at http://www.customs.eac.int/ index.php?option=com_content \&view=article\&id=106\&Itemid $=135$.

62 East African Community Customs Union (Rules of Origin) Rules, 2015 available at http://www.customs.eac.int/index.php?option=com_content\&view=article\&id=106\&Ite $\operatorname{mid}=135$.

63 East African Community Customs Union (Rules of Origin) Rules 2015; Rule 2 available at http://www.customs.eac.int/index.php?option=com_content\&view=article\&id=106\&Ite $\operatorname{mid}=135$. 
consigned. ${ }^{64}$ Rule 5 of the Rules of Origin sets out the criteria for determining products as wholly produced in the Partner States. The rule states:

1. For the purposes of rule 4 (a), the following products shall be regarded as wholly produced in a Partner State:

(a) mineral products extracted from the ground or sea-bed of the Partner State;

(b) vegetable products including plant and plant products harvested, gathered or picked within the Partner State;

(c) live animals born and raised within the Partner State;

(d) products obtained from live animals within the Partner State;

(e) products from slaughtered animals born and raised within the Partner State;

$(f)$ products obtained by hunting or fishing conducted within the Partner State;

(g) products of aquaculture, including mariculture, obtained within the Partner State where the fish is raised;

(h) products of sea fishing and other products taken from the exclusive economic zone of the Partner State;

(i) products of sea fishing and other products taken from the waters in the high seas by a vessel of a Partner State;

(j) products manufactured in a factory ship of a Partner State exclusively from the products referred to in sub-paragraph (i);

(k) products extracted from marine soil or subsoil outside the territorial waters of a Partner State provided that the Partner State has the sole right to work on that soil or subsoil;

(l) used articles fit only for the recovery of materials, provided that such articles have been collected from users within the Partner State;

$(m)$ scrap and waste resulting from manufacturing operations within the Partner State; and

(n) goods produced within the Partner State exclusively or mainly from the following -

i. products referred to in this paragraph; and

ii. materials which do not contain elements imported from outside the Partner State or which are of undetermined origin. 65

64 East African Community Customs Union (Rules of Origin) Rules 2015; Rule 4(1)(a).

65 East African Community Customs Union (Rules of Origin) Rules 2015; Rule 5(1). 
Secondly, goods will be considered as originating from the Partner States where the goods are produced in a Partner State incorporating materials which have not been wholly obtained in the Partner State provided that such materials have undergone sufficient working or processing in the Partner State. ${ }^{66}$

Products are considered to meet the criteria of being sufficiently worked or produced on a case-by-case basis when they meet the criteria provided for under the First Schedule of the Rules of Origin. ${ }^{67}$

The current Rules of Origin appear more complex than the previous rules which were based on the percentage of local material or value addition in the product. 68

Some processes are specifically indicated as not providing origin. These include packaging, bottling, placing in bags, simple mixing of ingredients, simple assembly of components, and simple painting or polishing. ${ }^{69}$

In determining the origin of the goods, energy and fuel; plant and equipment; machines and tools; and goods which do not enter and are not intended to enter into the final composition of the product are considered neutral elements and are not considered part of the goods. ${ }^{70}$

In order to obtain a Certificate of Origin, the Rule of Origins require that an application is made to the competent authority in the consignees Partner State and that application is to be accompanied by documents verifying that the goods meet the required criteria. ${ }^{71}$ The Certificate that is issued is valid for a period of six months. ${ }^{72}$

\subsection{Elimination of Non-Tariff Barriers to Trade}

Free movement of goods will not be achieved, even where the tariffs have been fully eliminated, unless non-tariff barriers are also eliminated. Non-tariff barriers (NTBs) are defined as any device or government practice that directly impedes the entry of imports into a country. They are restrictions other than tariffs that act as obstacles to trade and may be imbedded in government

66 East African Community Customs Union (Rules of Origin) Rules 2015; Rule 4(1)(b).

67 East African Community Customs Union (Rules of Origin) Rules 2015; Rule 6.

68 For discussion of previous rules see Henry Mutai, 'Regional trade integration strategies under SADC and the EAC: A comparative analysis' (2011) 1 SADC Law Journal 81-97 at 86.

69 East African Community Customs Union (Rules of Origin) Rules 2015; Rule 7.

70 East African Community Customs Union (Rules of Origin) Rules 2015; Rule 14.

71 East African Community Customs Union (Rules of Origin) Rules 2015; Rule 17.

72 East African Community Customs Union (Rules of Origin) Rules 2015; Rule 21. 
laws, regulations, practices and requirements at both the national and local levels. ${ }^{73}$ Article 1 of the EAC Treaty defines NTBs as "administrative and technical requirements imposed by a Partner State in the movement of goods. ${ }^{74}$ The Customs Union Protocol goes into more detail and defines non-tariff barriers as "laws, regulations, administrative and technical requirements other than tariffs imposed by a Partner State whose effect is to impede trade."75

The EAC Secretariat has attempted an operational definition and defines NTBS in the EAC as quantitative restrictions and specific limitations, other than tariffs, that act as obstacles to trade. Such obstacles, it observes, may be embedded in government laws, regulations, practices and requirements at the national and local level. A wide range of measures have the potential of falling within the scope of NTBs. A report prepared for the EAC in 2008 identified numerous NTBS, including non-recognition of EAC Certificates of Origin; import bans of various products including milk, dairy products, multiple road blocks and weighbridges; levies charged on various imports; and road consignment notes required of transports. ${ }^{76}$

Article 75 of the EAC Treaty provides that the Customs Union Protocol will cover amongst other things the elimination of non-tariff barriers. ${ }^{77}$ Article 13 of the Customs Union Protocol provides that:

1. Except as may be provided for or permitted by this protocol, each Partner State agrees to remove, with immediate effect, all the existing nontariff barriers to the importation into their respective territories of the goods originating in the other Partner States and, thereafter, not to impose any new non-tariff barriers.

2. The Partner States shall formulate a mechanism for identifying and monitoring the removal of non-tariff barriers. ${ }^{78}$

Given the wide variety of measures that can potentially be classified as NTBs the EAC Treaty and implementation organs have developed various approaches

\footnotetext{
73 Imen Trabelsi, 'Agricultural trade face to Non-Tariff barriers: A gravity model for the EuroMed area' (2013), 3 Journal of Studies in Social Sciences 1, 20-32.

74 EAC Treaty Article 1.

75 EAC Customs Union Protocol Article 1.

76 EAC, Implementation and Impact of the East African Community Customs Union (2009).

77 EAC Treaty Article 75(1)(c).

$78 \quad$ EAC Customs Union Protocol Article 13.
} 
to dealing with them. ${ }^{79} \mathrm{~A}$ number of institutions with the responsibility for monitoring the imposition of NTBs have been created. The monitoring is mainly done through reports and investigations. The institutions include the EAC Sectoral Committee on Trade, Industry, Finance and Investment; the EAC Trade Remedies Committee; the EAC Secretariat; and National Monitoring Committees.

The EAC Sectoral Committees are mandated under the EAC Treaty to monitor progress of implementation of the Treaty in their sectors and submit reports. ${ }^{80}$ The main Sectoral Committee for the elimination of NTBs is the Sectoral Committee on Trade, Industry, Finance and Investment.

The Trade Remedies Committee was established under Article 24 (1) of the Customs Union Protocol. ${ }^{81}$ The main duty of the Committee is to handle matters relating to rules of origin; anti-dumping measures; subsidies and countervailing measures; safeguard measures; and implementation of the Dispute Settlement Mechanism. ${ }^{82}$

National Monitoring Committees work through regional forums that enable the Partner States to exchange experiences. The National Monitoring Committees' reports are sent to the EAC Secretariat through the national ministries. ${ }^{83}$

In 2008, the EAC Council directed the Secretariat to develop a time bound mechanism for the elimination of current and future NTBs. ${ }^{84}$ The Secretariat developed the mechanism which guides the process of elimination of NTBS.

\subsubsection{The East African Community Non-Tariff Barriers Act, 2015}

The mechanisms discussed above have been criticised for their failure to significantly reduce NTBs in the EAC. ${ }^{85}$ The weakness led the East African Legislative

79 EAC, Status of Elimination of Non-Tariff Barriers in the East African Community (2014, Volume 8); Phyllis Osoro, 'The East African Community and Non-Tariff Barriers A Hindrance to the Trade Liberalisation Policy and Legal Proposals for Eliminating NonTariff Barriers', University of Nairobi LL.M. Thesis (2015).

$80 \quad$ EAC Treaty Articles 20, 21 and 22.

81 EAC Customs Union Protocol Article 24(1).

82 EAC Customs Union Protocol Article 24(4).

83 National Monitoring Committees...

84 EAC, East African Community Time Bound Programme for the Elimination of Non-Tariff Barriers, EAC Arusha 2008.

85 EAC (EABC), Monitoring Mechanism for Elimination of Non-Tariff Barriers in the EAC $<$ http://www.eac.int/news/index.php?option=com_docman\&task=doc_view\&gid=291\& Itemid $=158>$. 
Assembly to put in place the process of binding legislation to deal with NTBs. ${ }^{86}$ This process culminated in the enactment of the East African Community Elimination of Non-Tariff Barriers Act, 2015 on the 3oth March 2015. ${ }^{87}$ The Act awaits Presidential assent by the Heads of States of the Member States. Once it receives the necessary assent, it will be the basis for handling NTBs within the EAC.

The short statute has 18 sections divided into five parts. The objective of the Act is to facilitate trade, and create an environment conducive to the movement of goods within the region. ${ }^{88}$ The NTBs are categorised according to the World Trade Organisation (WTO) categories set out in the Schedule to the Act. ${ }^{89}$ The Schedule has categorised NTBs into seven categories. ${ }^{90}$ The categories are government participation in trade and restrictive practices tolerated by government; customs and administrative entry procedures; technical barriers to trade including standards, testing and packaging; sanitary and phytosanitary measures; specific limitations including quantitative restriction, exchange control, export taxes and quotas; charges on imports; and other procedural problems including arbitrariness, discrimination, costly procedures and documentation.

Bureaucratic activities of public officers and institutions of the Partner States which waste time and increase the cost of movement of goods are also specifically designated as NTBs to trade under the Act. ${ }^{91}$

National Monitoring Committees comprising representatives of both public and private sector representatives are to be established for each Partner State. ${ }^{92}$ The National Monitoring Committees, as the name suggests, are required to outline the process of elimination of NTBs in the respective Partner States and monitor the process. ${ }^{93}$ The National Monitoring Committees are to advise the Partner States on policies and laws that contain or lead to NTBs. Each Partner State is to identify a National Focal Point which is to be a particular Ministry to champion the elimination of NTBs. ${ }^{94}$

86 East African Legislative Assembly, Official Report of the Proceedings of the East African Legislative Assembly (Fifth Meeting - Fifth Session-Second Assembly, 2012).

87 The East African Community Elimination of Non-Tariff Barriers Act, 2015.

88 The East African Community Elimination of Non-Tariff Barriers Act, 2015 Article 3.

89 The East African Community Elimination of Non-Tariff Barriers Act, 2015 Article 4.

9o The East African Community Elimination of Non-Tariff Barriers Act, 2015 Schedule.

91 The East African Community Elimination of Non-Tariff Barriers Act, 2015 Article 6.

92 The East African Community Elimination of Non-Tariff Barriers Act, 2015 Article 7 \& 7(2).

93 The East African Community Elimination of Non-Tariff Barriers Act, 2015 Article 7(1).

94 The East African Community Elimination of Non-Tariff Barriers Act, 2015 Article 8. 
The Act sets out a procedure for the elimination of NTBs. The elimination is to be by mutual consent of Partner states; by implementation of the East African Community Time Bound Programme for Elimination of Identified Non-Tariff Barriers; and through directives of the EAC Council. ${ }^{95}$

The Act provides that where a Partner State fails to eliminate the Nтвs the Secretary General shall refer any matter that is not resolved by the Council to the EAC Committee on Trade Remedies. ${ }^{96}$ The Council may recommend to the Summit that sanctions are imposed on a Partner State that fails to comply with any directive, decision or recommendation of the Council. ${ }^{97}$

The Act has been criticised for being silent on what action is to be taken against a Partner State which fails to eliminate NTBs. ${ }^{98}$ The scheme of the Act may be faulted for relying on the potential beneficiaries of the NTBs for their elimination. The National Monitoring Committees comprising private and public sector officials of a Partner State may not be motivated to eliminate the NTBs that affect goods from third Partner States.

\subsection{Harmonisation and Development of EAC Standards}

As indicated above, the EAC has recognised that the application of standards can be classified as a NTB and hinder the free movement of goods. In 2001, in order to reduce the chances of the application of different standards acting as a barrier to the free movement of goods, the EAC Partner States concluded the East African Community Standardisation, Quality Assurance, Metrology and Testing Protocol. ${ }^{99}$ Furthermore, in 2006 the East African Legislative Assembly passed the East African Community Standardisation, Quality Assurance, Metrology and Testing Act, 2006, ${ }^{100}$ which is aimed at the further harmonisation of standards.

95 The East African Community Elimination of Non-Tariff Barriers Act, 2015 Article 9.

96 The East African Community Elimination of Non-Tariff Barriers Act, 2015 Article 12 \& 15.

97 The East African Community Elimination of Non-Tariff Barriers Act, 2015 Article 16.

98 Phyllis Osoro, 'The East African Community and Non-Tariff Barriers A Hindrance to the Trade Liberalisation Policy and Legal Proposals for Eliminating Non-Tariff Barriers' (2015) University of Nairobi LL.M.

99 The East African Community Standardisation, Quality Assurance, Metrology and Testing Protocol, 15th January 2001.

100 The East African Community Standardisation, Quality Assurance, Metrology and Testing Act, 2006. 


\subsubsection{The East African Community Standardisation, Quality Assurance, Metrology and Testing Protocol}

The EAC Standardisation, Quality Assurance, Metrology and Testing Protocol requires that Partner States evolve and apply a common policy on standardisation, quality assurance, metrology and testing of products which are produced and tested within the Community. ${ }^{101}$ A common policy on the relationship between the standard bodies in each Partner State, termed Bureauxs, must also be developed. ${ }^{102}$ The Protocol requires that Partner States develop capacity in standard enforcement. ${ }^{103}$ The Partner States are also required, by the Protocol, to recognise standards developed and adopted by the African Regional Organisation for Standardisation. ${ }^{104}$ The Protocol requires that Partner States apply uniform standards and procedures for formulation of national standards and must also adopt and implement East African Standards alongside these national standards.

\subsubsection{The East African Community Standardisation, Quality Assurance, Metrology and Testing Act, 2006}

The EAC Standardisation, Quality Assurance, Metrology and Testing Act, $2006^{105}$ has provided further legal force to the efforts for harmonisation of standards within the EAC. The Act establishes the East African Standards Committee, ${ }^{106}$ the Liaison Office, ${ }^{107}$ and the East African Accreditation Board..$^{108}$ Each of these bodies assists in the efforts towards harmonisation of standards.

\footnotetext{
101 Article 3.1 of The East African Community Standardisation, Quality Assurance, Metrology and Testing Protocol, 15th January 2001.

102 Article 3.1(b) of The East African Community Standardisation, Quality Assurance, Metrology and Testing Protocol, 15th January 2001.

103 Article 3.1(b) of The East African Community Standardisation, Quality Assurance, Metrology and Testing Protocol, 15th January 2001.

104 Article 4.1 of The East African Community Standardisation, Quality Assurance, Metrology and Testing Protocol, 15th January 2001.

105 The East African Community Standardisation, Quality Assurance, Metrology and Testing Act, 2006 Legal Notice No. 01/2007 of the East African Community.

106 The East African Community Standardisation, Quality Assurance, Metrology and Testing Act, 2006 Legal Notice No. 01/2007 of the East African Community Section 4.

107 The East African Community Standardisation, Quality Assurance, Metrology and Testing Act, 2006 Legal Notice No. 01/2007 of the East African Community Section 5.

108 The East African Community Standardisation, Quality Assurance, Metrology and Testing Act, 2006 Legal Notice No. 01/2007 of the East African Community Section 11.
} 
A detailed examination of the workings of these bodies would be beyond the scope of this work, ${ }^{109}$ however, a brief overview is given below.

Among other things, the Standards Committee is required to undertake and coordinate activities related to standardisation, including establishment of procedures for the development, approval, gazetting and withdrawal of East African Standards. ${ }^{110}$ The Liaison Office provides administrative support to the Standards Committee. The Liaison Office is the custodian of the catalogue and authoritative texts of the East African Standards that have been adopted. The East African Accreditation Board is made up of the chief executives of the national accreditation bodies. They seek to avoid duplication of functions at the national and regional levels.

Under Section 19 of the EAC Standardisation, Quality Assurance, Metrology and Testing Act, 2006, the Council may declare an East African Standard, or provision of the Standard, to be compulsory. Before such declaration, the Standard has to published in the East African Community Gazette and at least one newspaper of national circulation in each of the Partner States. The Standards Act provides sanctions for the manufacture or distribution of products not in conformity with the standards. The Act provides:

No person shall manufacture, trade, distribute, sell, supply or bring a product that is within the scope of a compulsory standard into the Community unless the product confirms with the requirements of the compulsory standard. ${ }^{111}$

Partner States are required to apply their national legislation in enforcement of the standards. ${ }^{12}$ Partner States are also required to ensure that their regulatory authorities suspend the manufacture, trading and distribution or sale of non-conforming products. Products that do not comply may be removed from the market, returned to the country of origin or confiscated and destroyed. ${ }^{113}$

109 For a summary see East African Community Understanding of the East African Community Legislation on Standardisation, Quality Assurance, Metrology and Testing Act (SQMT) Arusha.

110 The East African Community Standardisation, Quality Assurance, Metrology and Testing Act, 2006 Legal Notice No. 01/2007 of the East African Community Section 4.

111 The East African Community Standardisation, Quality Assurance, Metrology and Testing Act, 2006 s. 22(1).

112 The East African Community Standardisation, Quality Assurance, Metrology and Testing Act, 2006 s. 22(4).

113 The East African Community Standardisation, Quality Assurance, Metrology and Testing Act, 2006 Section 22(3) \& (4). 
A person aggrieved by a decision under this section may appeal to the East African Standards Committee within 14 days of the decision. ${ }^{114}$ The exact authority of the Committee within the domestic and regional judicial framework is not clear and there appears to be an area of potential conflict between the Committee and domestic courts.

Each Partner State is required to notify the Council of the product certification marks within the jurisdiction of the State. The Partner States are required to recognise as equal to their own, product certification marks awarded by national quality systems institutions of the other Partner States. ${ }^{115}$

Pursuant to the powers under Section 29 of the EAC Standardisation, Quality Assurance, Metrology and Testing Act, 2006, the Council of Ministers has made a number of regulations to govern standards making and implementation. ${ }^{116}$

\subsection{Free Movement of Goods and The Protocol on the Establishment of the East African Community Common Market}

The Protocol on the Establishment of the East African Community Common Market (Common Market Protocol) was signed on the 9th of November 2009, ten years after the signing of the EAC Treaty. ${ }^{117}$

\footnotetext{
114 The East African Community Standardisation, Quality Assurance, Metrology and Testing Act, 2006 Section 22(5).

115 The East African Community Standardisation, Quality Assurance, Metrology and Testing Act, 2006 Section 24(2) \& (3).

116 Subsidiary Legislation passed includes:

1) East African Community Standardisation, Quality Assurance, Metrology and Testing (Product Certification in the Partner States) Regulations, 2013. EAC Statutory Instruments Supplement No. 1 of 6th December 2013 EAC Gazette No. 15 6th December 2013. Uganda Printing and Publishing Corporation, Entebbe.;

2) East African Community Standardisation, Quality Assurance, Metrology and Testing (Enforcement of Technical Regulations in Partner States) Regulations, 2013. EAC Statutory Instruments Supplement No. 2 of 6th December 2013 EAC Gazette No. 15 6th December 2013. Uganda Printing and Publishing Corporation, Entebbe;

3) East African Community Standardisation, Quality Assurance, Metrology and Testing (Designation of Testing Laboratories) Regulations, 2013. EAC Statutory Instruments Supplement No. 1 of 6th December 2013 EAC Gazette No. 15 6th December 2013. Uganda Printing and Publishing Corporation, Entebbe.

117 EAC Common Market Protocol.
} 
Under the Common Market Protocol, the Partner States undertake to accord to each other's nationals treatment which is not less favourable than that accorded to nationals of third party states (Most Favoured Nation), and to observe non-discrimination of nationals of other Partner States on grounds of nationality (national treatment). ${ }^{118}$ In addition, under Article 5 (2)(c) of the Common Market Protocol, the Partner States agree to eliminate tariff, nontariff and technical barriers to trade; harmonise and mutually recognise standards; and implement a common trade policy for the Community. ${ }^{119}$

Part C of the Common Market Protocol covers the free movement of goods. Article 6 of the Common Market Protocol indicates that the free movement of goods between the Partner States of the Community is to be governed by the Customs law of the Community specified in Article 39 of the Customs Union Protocol. ${ }^{120}$ In addition to the Customs law of the Community, the free movement of goods is to be governed by:

(a) The East African Community Protocol on Standardisation, Quality Assurance, Metrology and Testing;

(b) The East African Community Standardisation, Quality Assurance, Metrology and Testing Act, 2006;

(c) The provisions of the Customs Market Protocol;

(d) Other protocols that may be concluded in the areas of cooperation on sanitary and phyto-sanitary and technical barriers to trade; and any other instrument relevant to the free movement of goods. ${ }^{121}$

\subsection{Free Movement of Goods in the East African Community Theory and Reality}

In this part of the Chapter we look at the theory of the EAC free movement of goods regime as spelt out in the regional legal regime reviewed above, against the reality of its implementation. In the last few years, with the assistance of the World Bank, "Score Cards" on the implementation of the EAC Treaty which track the implementation of the provisions of the EAC Treaty and the

\footnotetext{
118 EAC Common Market Protocol Article 3.

119 EAC Common Market Protocol Article 5(2)(a).

120 EAC Common Market Protocol Article 6(1).

121 EAC Common Market Protocol Article 6(2).
} 
protocols have been prepared. ${ }^{122}$ The 2014 Score Card notes that the laws and regulation of the Partner States continue to be a barrier to increased cross-border trade. The progress to eliminating restrictions is slow and new measures are introduced despite the provisions of the protocols. There is, according to the 2014 Score Card, a lenient attitude towards exemptions which is consequently slowing down the development of the EAC Common Market.

The 2014 Score Card notes that, although formally all Partner States have eliminated tariffs on intra-regional trade, measures of equivalent effect to tariffs still remain. It is noted, for example, that certificates of origin are often not recognised by the Partner States. It is also noted that although the Common External Tariff is formally in place, it is not implemented fully due to the fact that the EAC Partner States belong to a multiplicity of different free trade areas.

The 2014 Score Card evaluates the extent to which the Partner States have implemented their obligations under Article 5(2(c)of the Customs Union Protocol. The areas evaluated are, the elimination of tariffs and measures of equivalent effect; the elimination of NTBs; the implementation of a common external tariff and the harmonisation of mutual recognition of sanitary and phytosanitary standards; and standards preventing technical barriers to trade. $^{123}$ The general consensus is that more could be done by the Partner States for the Community in order to fully realise free movement of goods within the EAC.

\subsection{Conclusion}

This Chapter briefly described the EAC regime for the free movement of goods. It has been noted that the current structure of the free movement of goods is

122 East African common market scorecard 2014: tracking EAC compliance in the movement of capital, services and goods (Vol. 2): Main report (English), The World Bank/ EAC Secretariat, 4 <http://documents.worldbank.org/curated/en/2014/o1/23862386/eastafrican-common-market-scorecard-2014-tracking-eac-compliance-movement-capitalservices-goods-vol-2-main-report> accessed June 28 2016; see also Maximillan Haller, 'The East African Community (EAC) The Difference between theory and practice based on the example of free movement of goods and services' (University of Sussex, 2014) Master of Arts.

123 East African Common Market Score Card, 2014: tracking EAC compliance in the movement of capital, services and goods (Vol. 2): Main report (English), The World Bank/ EAC Secretariat, $4<$ http://documents.worldbank.org/curated/en/2014/01/23862386/eastafrican-common-market-scorecard-2014-tracking-eac-compliance-movement-capitalservices-goods-vol-2-main-report> accessed June 282016 . 
informed by the historical relationships between the Partner States and their experiences, in part experiments, with cooperation. It has been noted that the Customs Union Protocol is very clear on the free movement of goods. In theory free movement of goods is operative within the Community. However, it has been noted that the existence of exceptions and the overlapping membership of regional trade regimes affects the effective implementation of the free movement of goods. There is also discord between the commitments that the Partner States have to free movement of goods and the reality as indicated by their domestic legislation. 